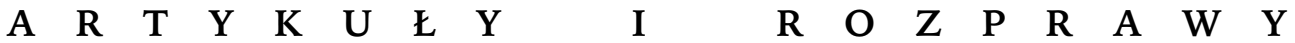

MARIANNA MICHAŁOWSKA

Uniwersytet im. Adama Mickiewicza w Poznaniu

\section{PORTRET WE WNĘTRZU \\ - MIĘDZY SOCJOLOGIĄ A ANTROPOLOGIĄ FOTOGRAFII}

Wnętrza prywatne i publiczne; przepełnione przedmiotami, lecz pozbawione ludzkiej postaci. Autorzy: Candida Höfer, Weronika Łodzińska-Duda, Andrzej Kramarz. Chciałabym tu prześledzić drogę, jaką fotografia przeszła od obrazu wnętrza będącego tłem dla postaci ludzkiej do fotografii wnętrza, w którym figura człowieka się nie pojawia, a które mimo to nadal reprezentuje jego mieszkańców. Rozważania są inspirowane dwiema tradycjami badań: $z$ jednej strony refleksją o fotografii w nurcie socjologicznym, $z$ drugiej wątkami antropologicznymi. Wydawałoby się, że między obiema perspektywami zachodzi istotna różnica (jeśli nie konflikt). Jednak dzięki osadzeniu fotografii w konkretnych praktykach społecznych można potraktować rozpoznania socjologii („kto i jak używa fotografii?”) jako podstawę do dalszych rozważań antropologicznych (,jakie znaczenia dla jednostki mają określone obrazy?”). Ta pierwsza wyznacza zatem horyzont myślowy, druga nakreśla kierunek, w którym podążamy. Dzięki temu możemy sformułować odpowiedź na pytanie, jaką rolę $w$ reprezentacjach odnoszących się do podmiotowości ludzkiej odgrywa architektoniczne „wnętrze” oraz $\mathrm{W}$ jakim stopniu sfotografowany przedmiot odpowiada metaforze „wnętrza” świadomości ludzkiej?

\section{DYSKURS SPOŁECZNY I ANTROPOLOGICZNY W FOTOGRAFII}

W pierwszym zdaniu klasycznego już tekstu Pierre'a Bourdieu (1990, s. 1) padają znamienne słowa: „czy jest możliwym i koniecznym dla praktyki fotograficznej i znaczenia obrazu fotograficznego dostarczanie materiału dla socjologii?”. Pozytywna odpowiedź przychodzi wkrótce, wraz z krytyką esencjo-

Adres do korespondencji: Instytut Kulturoznawstwa UAM, ul. Szamarzewskiego 89, 60-568 Poznań. 
nalistycznego podejścia do fotografii, oraz dzięki dążeniu do unikania „pokus intuicjonizmu”, które pojawiają się wraz z „codziennymi banałami na temat czasu, erotyzmu i śmierci" (Bourdieu 1990, s. 9). Czytanie fotografii, w opinii francuskiego badacza, jest przydatne wtedy, gdy obrazy fotograficzne moga dostarczyć nam konkretnej wiedzy: na temat przyczyn ich powstawania oraz życia ich użytkowników. Bourdieu nie pyta: ,jak te fotografie są zrobione?”, ale „po co je zrobiono i w jakich celach teraz ich się używa?"

Warto zwrócić tu uwagę, że w Polsce odkrycie myśli Bourdieu dla fotografii dokonało się w tym samym czasie, gdy odkrywano doniosłość jego koncepcji dla socjologii. W jednym z esejów publikowanych w „Fotografii” w 1983 r. Urszula Czartoryska (2005a, s. 122), przywołując tekst francuskiego socjologa, pisała: „fotografia, w przeciwieństwie do innych rzemiosł i hobby (rysunku, muzyki i tym podobnych) przez domniemaną wolność od kodów i reguł, estetyk, uważana być może przez uważnego socjologa za narzędzie odsłaniające konwencje i oczekiwania usztywnione przez tradycję środowiska”. Fotografia jawi się zatem jako narzędzie przede wszystkim podtrzymywania, lecz czasem również przełamywania określonych konwencji fotograficznych.

Drugie ważne spostrzeżenie w refleksjach Bourdieu na temat fotografii idzie w parze $z$ jego koncepcją kapitału kulturowego i dotyczy związku między praktykami związanymi z fotografią (np. używaniem fotografii jako symbolu statusu społecznego) a hierarchią społeczną. Bourdieu (1990, s. 9) pisze: „związek między jednostkami a praktyką fotograficzną jest zasadniczo relacją pośrednią, ponieważ zawsze zawiera odniesienie do relacji z fotografią, którą nawiązują przedstawiciele innych klas społecznych i do całej struktury relacji pomiędzy klasami”. Każde użycie fotografii jest uzasadnione w kontekście określonych warunków społecznych. Jak zauważa badacz, inaczej i co innego fotografują robotnicy, inaczej fotografowie-amatorzy z klasy średniej aspirujący do miana parających się sztuką. Inne będą motywacje, inne wybory estetyczne (determinowane zarówno możliwościami finansowymi, jak i świadomością estetyczną) (Bourdieu 1990, s. 14-15). Wybór socjologicznego spojrzenia na fotografię rzutuje także na specyficznie ujmowaną kwestię obiektywizmu fotografii, osadzonego nie w związku obrazu z pojęciem „natury”, lecz w jej społecznym sensie. „Właśnie dzięki swym licznym «użytkom społecznym» fotografia - selekcjonując motywy wśród ustalonych struktur i organizując nam wspólną wizję świata - sprawia, że — komentuje Czartoryska (2005a, s. 130) — obrazek fotograficzny akceptujemy jako wiarygodny".

Podejście francuskiego socjologa reprezentuje pewien nurt badań nad fotografią, w którym badacza interesuje świat społeczny oraz znaczenia kulturowe wytwarzane przez jednostkę. Porzucony zostaje zatem „projekt antropologiczny na rzecz innych nauk" (Bourdieu 1990, s. 1). Należy jednak zadać pytanie o cel badawczy, który stawia sobie socjolog, a tym bez wątpienia nie jest analiza estetycznych założeń obrazu lub intencji twórczej artystów, lecz sprawdzenie, jak fotografia funkcjonuje społecznie. Dopiero wraz z tym fundującym 
założeniem fotografia zyskuje odpowiednią perspektywę, stając się środkiem pozwalającym nam dotrzeć do wiedzy o społeczeństwie.

W podobny sposób odnosił się do fotografii John Tagg w książce The Burden of Representation. Najbardziej przez niego krytykowanym podejściem była fenomenologiczna interpretacja fotografii proponowana przez Barthesa w Swietle obrazu. Według Tagga, podejście fenomenologiczne, nacisk na wewnętrzne sensy i pozaobrazowe przeczucia, naraża obraz na skażenie intuicjonizmem (podobne sformułowanie można odnaleźć na stronach książki Bourdieu). Ważniejszy od niejasnego „intuicjonizmu” miał tu być związek instytucji społecznych i medium oraz ich standaryzujący wpływ na życie jednostek. Niejasnego świata przeczuć powinien natomiast unikać badacz, dla którego fotografia staje się źródłem, jakkolwiek niepewnym, wiedzy o relacjach społecznych (Tagg 1988, s. 3). Podejście Bourdieu i Tagga nakierowane jest na społeczeństwo, lecz także ono (jak każda próba teoretyzacji) okazuje się narzędziem dopasowanym jedynie do pewnych aspektów badania kultury. Społeczny dyskurs fotografii dostarcza informacji głównie na temat zdrowego rozsądku (common sense) społeczeństwa, lecz nie zawsze jest skuteczny, gdy badamy praktykę artystyczną i chcemy dotrzeć do znaczeń poza common sense wykraczających.

I tutaj z pomocą przychodzi perspektywa antropologii fotografii reprezentowana przez Johna Bergera czy Terence'a Wrighta (a w polskiej literaturze chociażby przez teksty Sławomira Sikory [2004]), którzy zmierzają do odkrycia sposobu ludzkiej percepcji fotografii oraz wiązanych $z$ nią znaczeń symbolicznych. Aby dostrzec znaczące różnice stanowisk badawczych socjologii i antropologii, wystarczy z tekstem Bourdieu zestawić zbiór esejów Bergera zatytułowany O patrzeniu. Tam także, w eseju z 1978 r. pt. Użycia fotografii (Berger 1999, s. 71-89), czytamy o „użytkach” płynących z fotografii, relacji obiektywizmu do subiektywizmu czy sfery publicznej do prywatnej, jednak Berger na pytania o społeczeństwo odpowiada spoglądając przez pryzmat obrazowych znaczeń. Interesują go sposoby budowania narracji, osadzania obrazu w kontekście kulturowym, umiejętności „czytania” obrazu. Fotografia powraca do rzeczywistości nie tylko pojęciowo przez społeczeństwo konstruowanej, lecz także fizycznej. To „rzeczywisty ślad” (Berger 1999, s. 74), interpretowany w kontekście społecznych użyć. Co interesujące, nie zakłada się tu intuicjonizmu, lecz raczej badanie obrazu, którego osadzenie w konkretnym kontekście użycia pozwala na dotarcie do znaczeń publicznych i prywatnych (to owe dwa podstawowe „użycia” medium). Fotografie bowiem to nie tylko konwencje, lecz również pamięć ludzka. Relację między podejściem społecznym i antropologicznym porównałabym do relacji opisu i interpretacji.

Zdjęcia dostarczają nam warstwy opisowej, podejście badawcze — poziomu interpretacyjnego. Zadaniem badacza (zarówno socjologa, jak i antropologa) nie jest przecież powtarzanie informacji utrwalonych na obrazie, lecz ich „rozszyfrowywanie", interpretowanie tak, by mogły dostarczyć możliwie najwięcej informacji o ludziach, którzy fotografii używają (nie tylko są fotografami, lecz 
także osobami portretowanymi czy oglądającymi gotowy obraz). Portretem fotografowanego człowieka jest nie tylko jego/jej wizerunek na zdjęciu, lecz także samo użycie aparatu fotograficznego. Jednak warstwa opisowa, chociaż dostarcza impulsów do interpretowania, ciągle nas zwodzi - ponieważ nasz odbiór fotografii odbywa się przecież na poziomie tekstowym. Używamy języka, by opisać, co widzimy, i w zależności od słów, których użyjemy, opisywany obraz się zmieni, co wpływa na późniejszą interpretację. Sam obraz nie dostarcza nam, tak jak tekst, jasnego kryterium sensu. Zatrzymajmy się przez chwilę przy funkcjach opisu.

Funkcja opisu, nawet w ujęciu literaturoznawczym, chociaż tak szeroko omawiana, często pozostaje rozpoznawana jedynie intuicyjnie. Phillipe Hamon (2004, s. 235) zauważa: „możemy określić opis jako rozwinięcie opowiadania [...], wypowiedź ciągłą lub nieciągłą, jednolitą pod względem predykatów i motywów, której zakończenie nie rzutuje na dalszy ciąg opowiadania [...]". W istocie opis wprowadza „tematykę pustą i redundantną", a przez to sprawia, że tekst coraz bardziej zaczyna odnosić się sam do siebie (Hamon 2004, s. 257). Opis w takim ujęciu będzie przeszkadzać opowiadaniu. Jednak opis zawsze związany jest z patrzeniem. Opisuje to, na co patrzą bohaterowie, lub rysuje scenę, na której czytelnik powinien zobaczyć bohaterów. „Zadaniem pisarza realisty będzie więc przekształcenie tematyki pustej w tematykę pełną; powierzenie sąsiadującym ze sobą spojrzeniom, ośrodkom przezroczystym itd. jakiejś roli w opowiadaniu, aby nie były tylko wypełnieniem pustych miejsc" (Hamon 2004, s. 257).

Na pierwszy rzut oka wydaje się, że fotografia jako opis obejmuje problematykę zupełnie inną niż opis literacki. W fotografii nie ma tematyki „pustej”, fotografia bowiem wypełniona jest elementami obrazu, tutaj nie ma warstwy opowiadania, z którą opis mógłby się ścierać. Jednak kiedy Berger (1999, s. 66) pisał, że „najlepsze fotografie są niezwykle gęste”, to zakładał, że każdy z elementów obrazowych będzie służył zbudowaniu znaczenia. Fotograficzny sposób komunikowania znaczeń jest także rodzajem opowiadania. Dlatego fotografowie skupiają się na ważnych elementach obrazu, by z fragmentów opisu można było przejść do poziomu opowiadania. Jak dokonuje się takie działanie, Berger pokazuje na przykładzie fotografii Paula Stranda. Czytamy jak Strand, dzięki umiejętności wyboru miejsca ustawienia kamery, „nie korzystając z anegdoty, przekształca sfotografowane obiekty i podmioty w narratorów" (Berger 1999, s. 64). Przejście od opisu do opowiadania sprawia, że elementy wizualne stają się czynnikami działania. Skupienie się na badaniu prac wielkich fotografów: Stranda czy Sandera, wskazuje na odmienne od socjologicznego sformułowanie zadania badawczego. Nie bez powodu w tym ostatnim bada się prace amatorów, społeczną produkcję masową - to te dane pozwalają nam rozpoznawać w zdjęciach konwencje i rytuały kulturowe. Jednak Strand i Sander poprzez swoje praktyki fotograficzne sami przyjmowali postawę badawczą wobec społeczeństw. Dlatego Berger nie może zadawać pytania: kto i jak używa 
fotografii?, lecz raczej: jaką wiedzę społeczną chciał przekazać nam autor obrazu?

Powstanie fotografii, które za chwilę poddamy interpretacji, jest uzasadnione konkretnymi odczytaniami kontekstu społecznego. Fotografowie wybierają $\mathrm{w}$ pełni świadomie medium fotograficzne, by prowadzić własne społeczne rozpoznanie.

\section{PORTRET WE WNĘTRZU}

Fotografia wypracowała co najmniej kilka możliwości usytuowania relacji wnętrza do sfotografowanej $\mathrm{w}$ nim osoby. W epoce wczesnej fotografii portretowej (1840-1850) wnętrze stanowi jedynie neutralne tło dla twarzy ludzkiej. Stopniowo jednak wnętrze zakładu fotograficznego zmienia się w inscenizacje, które mają dostarczać nam wiedzy o statusie lub tylko nastroju fotografowanego. Pojawiają się portrety „salonowe”: modele siadają na pluszowych kanapach, stylowych fotelach ustawionych na tle namalowanego panneau, imitującego szacowność salonu, a także portrety romantyczne z tłem pejzażowym: aleją drzew, parkiem angielskim, sielskim krajobrazem. Wnętrze zakładu fotograficznego reprezentuje wszechświat możliwości, w jakich chcielibyśmy być oglądani przez innych. To epoka fotografii mieszczańskiej, opisywanej przez Waltera Benjamina (1996a, s. 113): „W tym to czasie powstały owe ateliers z draperiami i palmami, gobelinami i sztalugami, które tak dwuznacznie oscylowały między egzekucją a reprezentacją, miejscem tortur a salą tronową". Nawet zdjęcia zrobione na zewnątrz wyglądają, w opinii autora Małej historii fotografii, jakby robiono je we wnętrzu. Przykładu dostarcza tu praktyka Davida O. Hilla i Roberta Adamsona, którzy w latach pięćdziesiątych wieku XIX portretowali swych modeli na edynburskim cmentarzu (ze względów technicznych). „I rzeczywiście cmentarz ten [...] przypomina jakieś wnętrze, odosobnione, odgrodzone pomieszczenie, gdy wsparte o ognioochronne mury wznoszą się $z$ trawnika nagrobki, wydrążone niczym kominy, zamiast języków ognia ukazujące w swym wnętrzu napisy" (Benjamin 1996a, s. 111). Inna sprawa, że często później owe fotograficzne portrety służyły Hillowi, by na ich podstawie mógł namalować „prawdziwe”, a więc cenione wśród społecznej elity, malarskie portrety. Zauważmy, że współczesne inscenizacje zakładowej fotografii ślubnej kontynuują tę tradycję wraz z jej teatralnym sztafażem.

O ile zakłady fotograficzne starannie przechowały konwencję mieszczańskiego portretu, o tyle $\mathrm{w}$ praktyce fotografów-dokumentalistów aparat fotograficzny wychodzi z zakładu na zewnątrz (jak w serii dokumentującej petits metiérs - „drobne zawody” Atgeta) lub wkracza we wnętrza prywatne. Stawia się go teraz w domu fotografowanego, wśród autentycznych rekwizytów. Ten typ portretowania, wypracowywany na przełomie wieków, punkt kulminacyjny osiąga w pierwszej połowie XX wieku. Wkrótce staje się typowy przede wszystkim dla praktyk etnograficznych i socjologicznych. Zdjęcie traktowane 
jest wówczas jako szczególnego rodzaju baza danych, którą później badacz podda interpretacji. Strój, rysy twarzy, otaczające przedmioty opisują sytuację społeczną fotografowanego, dzięki czemu rozszyfrujemy jego przynależność do grupy społecznej. W istocie fotografowie stosują $\mathrm{w}$ ten sposób podejście neorealistyczne. Modele powinni być jak najbardziej „naturalni”, jak najmniej „upozowani”. Jednak cel fotografii — podobnie jak we włoskim neorealizmie filmowym - jest podszyty ideologią. Tę strategię odnajdujemy w klasycznym dokumencie wieku XX - w pracach Augusta Sandera i niektórych pracach $z$ amerykańskiego projektu Farm Security Administration.

Tu nas interesuje jednak przede wszystkim relacja przedmiotów i postaci ludzkiej. Na portretach łączonych z nurtem fotografii socjologicznej człowiek i przedmiot potwierdzają wzajemnie swoje miejsce. Człowiek zostaje opisany poprzez rzeczy, których używa. Sanderowski cukiernik został sportretowany w teatralnym geście naśladującym zwykłą, codzienną czynność. Stoi sztywno pozując, świadomy wagi aktu „portretowania”. Tę samą oficjalną powagę wyrażają postaci z „Zapisu socjologicznego" Zofii Rydet. Mieszkańcy polskiej wsi zostali przez autorkę sfotografowani w swoich domach. Widzimy ich w różnych pozach: wspartych o kant stołu, opartych o piec, z dłońmi ułożonymi prosto na kolanach. Za nimi na ścianach (z drewnianych bali lub bielonych wapnem) są zawieszone święte obrazki. Równie często pojawiają się portrety fotograficzne ich samych w młodości. Wszyscy: kobiety i mężczyźni, zdają się lekko uśmiechać, lecz jest to uśmiech postaci onieśmielonych obecnością fotografki, której pozwolili wejść do swego wnętrza. Teraz wyczekują dźwięku migawki.

Fotografia socjologiczna dokonywała wyraźnej klasyfikacji swoich modeli - wpisywała ich w określony kontekst. Cyrkowiec stawał się przede wszystkim cyrkowcem, ponieważ widzieliśmy go na tle wozu cyrkowego (Sander), a wiejska kobieta (Rydet) już na zawsze została wpisana w świat wyznaczony ścianami jej domu. Sander pisze o portrecie meksykańskiej kobiety Stranda, że zdjęcie pokazuje, jak bycie (istnienie dla samej siebie) kobiety „prześwituje przez materializm tego obrazu” (cyt. za: Berger 1999, s. 66). Jednak to „bycie" wyrażać się będzie właśnie w przedmiotach, które zostały nam pokazane: w plecionym koszu, wełnianym okryciu. Ona ,jest sobą" poprzez przedmioty. W projektach socjologicznych powtarzalność sfotografowanych wnętrz sprawia, że indywidualna tożsamość portretowanych jest równoważona wiedzą o portretowanych. Moglibyśmy w prowokacyjny sposób odwrócić tezy Bourdieu (a w pewnym sensie i Benjamina). Dla niego to zmasowana produkcja amatorska stanowiła bazę danych do klasyfikowania społeczeństwa. „Zmasowanie fotografii to nie tylko atlas, ale wizerunek psychiczny społeczeństwa i, co więcej, wizerunek i lustro społeczeństwa, które fotografiom się przypatruje" — komentuje to Czartoryska (2005b, s. 111). Dodajmy jednak, że zmasowanie portretów członków grup społecznych równie skutecznie tworzy ich wizerunek. Indywidualność poszczególnych osób patrzących prosto w obiektyw aparatu fotograficznego gubi się, a oni stają się reprezentacją świata społecz- 
nego, który reprezentują. Dzieje się tak dzięki uznaniu, że tożsamość osoby i przedmioty należące do niej wzajemnie się uzupełniają. Także ta konwencja fotografowania ulega przekształceniu: poza portretami we wnętrzu coraz częściej trafiamy na przykłady, w których wnętrze zaczyna funkcjonować przede wszystkim w znaczeniach symbolicznych.

Inaczej jednak dzieje się w pracach świadomie odchodzących od idei społecznej klasyfikacji na rzecz szukania indywidualnych przeżyć (Wolfgang Tilmanns, Nan Goldin). Tutaj „wnętrze” zaczyna znaczyć nie architektoniczne otoczenie człowieka, lecz jego duchowe wyposażenie. Wnętrza na fotografiach Nan Goldin nie potwierdzają tożsamości osoby. O takich pokojach hotelowych, wynajmowanych mieszkaniach mówimy, że są właśnie „bezosobowe”. Sportretowani, inaczej niż $\mathrm{w}$ dokumentach społecznych, nie patrzą $\mathrm{w}$ obiektyw. To odwrócenie wzroku sugeruje „zamknięcie” przed widzem. Dlatego też wydają się zagubieni, pogrążeni we własnym wnętrzu. Na zdjęciu „Nan and Brian in Bed, New York City" (1983) nagi mężczyzna siedzący na łóżku nie patrzy na leżącą na tym samym łóżku kobietę (autorkę). Ona patrzy na niego $z$ ukosa. Światło padające z okna wydobywa niewiele szczegółów pomieszczenia: ozdobna rama łóżka, fragmenty fotografii. Tylko na ścianie nad łóżkiem widzimy zdjęcie wyraźniejsze - to portret mężczyzny z papierosem w ustach, być może tego samego (również palącego), który pozował do zdjęcia. Nie chodzi już o ukazanie tożsamości osób, lecz o zobrazowanie wzajemnych relacji. Wygląd wnętrza uwypukla wzajemną alienację bohaterów. Zauważmy zatem, że wnętrze pełni tutaj istotną funkcję $\mathrm{w}$ budowaniu narracji dotyczącej historii dwojga ludzi.

Podobny nastrój wyrażają fotografie amerykańskiego fotografa Todda Hido. W cyklu jego prac „Between the Two" ${ }^{1}$ portrety młodych kobiet w hotelowych wnętrzach są prezentowane obok fotografii samych wnętrz. Fotografie te, jak sądzę, należy czytać wspólnie. Puste spojrzenia modelek uzupełniają puste wnętrza pokoi. Porównajmy dwie prace: na pierwszej w centralnej części zdjęcia światło padające $z$ okna wydobywa postać kobiety. W prawej części obrazu widać, jak lekko światło prześwituje przez tkaninę zasłony, w lewej części zauważamy telefon niemal ginący w cieniu. Druga fotografia pokazuje narożnik pokoju i lekko uchylone drzwi. Podobnie jak Goldin, Hido kolejnymi kadrami buduje niemal filmową narrację. Napięcie odczuwalne w każdym z kadrów sugeruje, że za chwilę coś się zdarzy. Powróćmy do pytania, które sobie tu stawiamy: jaką funkcję pełnią w tym cyklu wnętrza? Należy potraktować ich rolę podobnie jak filmowej scenografii: $z$ jednej strony obrazują emocjonalny stan postaci, z drugiej są czynnikiem konstruującym narrację. Są zatem — jak nazywa to Anthony Vidler (1999, s. 17) — przykładem „przestrzeni psychicznej”. Jednak wnętrza w pracach Hido nie opisują tożsamości jego bohaterów.

\footnotetext{
${ }^{1}$ Prace Todda Hido były prezentowane w Yours Gallery w Warszawie. Materiały dzięki uprzejmości Galerii.
} 
Nie wiemy, kim jest półnaga kobieta na zdjęciu. Znamy jej zachowania, lecz nie znamy jej przynależności społecznej, zawodowej, klasowej. Bez wątpienia czeka na kogoś, na telefon, może jest ukrywającą się bohaterką historii kryminalnej, a może tylko porzuconą kochanką? Jest więc to portret we wnętrzu, ale nie jest to $\mathrm{w}$ istocie portret osoby, lecz fragment historii.

Przywołajmy tu jeszcze jeden cykl fotografii. Tym razem będą to cyfrowo przekształcane obrazy Anthony'ego Aziza i Samiego Couchera zatytułowane „Interiors” (Wnętrza). Co widzimy? Architektoniczne formy, kojarzące się z korytarzem, pokojem, drzwiami $z$,judaszem". Jednak te fragmenty wnętrz zostały powleczone ludzką skórą. Kiedy zastanawiamy się nad sensem takiego zestawienia, pojawiają się interesujące konotacje. Oto skóra, która przecież jest na zewnątrz naszego ciała, zaczyna okrywać wnętrze. Co prawda, nie widzimy twarzy ludzkiej, samo użycie cielesnej struktury sugeruje obecność człowieka. Te wnętrza pełnią rolę czysto metaforyczną, są dwuznaczne. Jednocześnie okrywają i odkrywaja, bronią przed zewnętrzem i pozwalają kontaktować się ze światem. Odpowiadają stanowi, który — w opinii Gastona Bachelarda (1994, s. 212) - formuje dialektykę wnętrza i zewnętrza. Fenomenolog ten zauważa, iż podział ów: „ma ostrość dialektyki «tak» i «nie», która o wszystkim decyduje” (Bachelard 1994, s. 211). Jednak dalsze rozważania prowadzą go do dostrzeżenia różnych asymetrii tego pozornego podziału. Metafory wnętrza i zewnętrza wcale nie są sobie równe. Co więcej, w zależności od punktu, z którego patrzymy, zawsze mogą zamienić się miejscami. Najciekawsze jednak wydaje się to, co jest pomiędzy nimi: „Jeśli istnieje linia graniczna powierzchni pomiędzy wnętrzem i zewnętrzem, to owa powierzchnia jest bolesna po obu stronach" (Bachelard 1994, s. 218).

Tę granicę w niezwykły sposób mogłyby ilustrować fotografie Aziza i Couchera. Skóra oblekająca wnętrze wyznacza wewnętrzną granicę zewnętrzności. Jednak fotografie te mogą pełnić jeszcze inną rolę $w$ tej argumentacji, ponieważ chociaż nie są to portrety, to nadal reprezentują istotę ludzką. Potraktujmy te fotografie jako szczególnego rodzaju pomost między fotografiami, na których ludzka postać jest zarejestrowana, a tymi, które tego wizerunku są pozbawione. Stykamy się z bardzo specyficznym wnętrzem mieszkalnym, wnętrzem tak bardzo przyswojonym przez człowieka, że staje się jego wewnętrznym, intymnym mieszkaniem.

\section{WNĘTRZE JAKO PORTRET}

W przeciwieństwie do portretu zakładowego w praktykach socjologicznych od XIX wieku widok osób na zdjęciu nie był niezbędny, by można było wypowiadać się na temat ich społecznej egzystencji. Mam tu na myśli projekty, których autorzy świadomie zajmują określoną pozycję wobec kontekstu społecznego, a ich celem jest najczęściej zmiana sytuacji społecznej przez działania instytucjonalne. Fotografie Camerona z Leeds, czy Marville’a z Paryża nie 
pokazują ludzi, lecz jedynie miejsca, w których oni żyją. Mają te prace wymiar społeczny, miały bowiem służyć przebudowie społeczeństwa — zamianie slumsów w „miejsca do życia”. Ktoś mógłby zapytać, dlaczego w kontekście fotografii wnętrz przywołuję fotografie robione „na zewnątrz”. I tu pojawia się drugi wymiar tych zdjęć - ich wymowa symboliczna. Te miejskie fotografie, przedstawiające zaułki i zapomniane uliczki, pokazują dokładnie to samo, co rozumiemy tu przez „wnętrze” - miejsce zamieszkane, miejsce, w którym przyszło żyć mieszkańcom nowoczesnych miast. Nie przywołując całej filozoficznej problematyki zamieszkania w tradycji Heideggerowskiej (Heidegger 2007, s. 139-157), zauważmy tylko, że owo zamieszkanie tutaj oznacza przede wszystkim proces myślenia. Miasto zamieszkane oznacza miasto przyswojone mentalnie.

Przywołane fotografie ciekawe są w kontekście filozoficznym. Miejskie slumsy obrazowałyby bowiem, mimo fizycznego ich zamieszkania (czy wręcz w wyniku zatłoczenia - „nadmiernego mieszkania”), niemożliwość zamieszkania mentalnego. Robotnicze miasto jest tylko miejscem do spania, w którym niemożliwe jest życie. Jak rozumieć słowa filozofa: „tylko gdy umiemy mieszkać, możemy budować”? (Heidegger 2007, s. 155). Hanna Buczyńska-Garewicz (2006, s. 166) komentuje: „zamieszkiwanie więc nie ma w sobie nic fizycznego". I dalej pisze o świadomości zamieszkiwania, o jego zakorzenieniu w myśleniu, „otwartości człowieka na wielość i różnorodność sensów emanujących z rzeczy". Pierwszym stopniem jest zatem nauczenie się mieszkania, które później posłuży budowaniu. Czemu służyły społeczne projekty fotograficzne? Czyż nie miały być ukazaniem miejsc „nie do życia”, „nie do mieszkania”? W konsekwencji miały służyć wykazaniu konieczności przebudowy. Ich rola polegała zatem na stopniowym uświadamianiu ludziom, czym jest prawdziwe „mieszkanie”, a następnie na stworzeniu impulsu „budowania”. Przedstawiona tu interpretacja może wydawać się naciągana zarówno w stosunku do myślenia filozofa, jak i samych fotografii, jednak pozwala zmienić sposób patrzenia na projekty dokumentalne, których dzisiejsze odczytanie (nasze spojrzenie w przeszłość) wyjmuje je z kontekstu społecznych uwarunkowań i nadaje im znaczeń symbolicznych.

Także według Gastona Bachelarda pojęcie „zamieszkiwanie” wykracza poza sferę fizyczną i zasadniczo stanowi metaforę przestrzenną, określającą sposoby egzystencji ludzkiej w świecie. Jak zauważa Buczyńska-Garewicz (2006, s. 222), Heideggera i Bachelarda podejścia do rozumienia zamieszkiwania różnią się zasadniczo - jeżeli według pierwszego na pierwszy plan wysuwa się „istnienie rozumiejące bycie”, to dla drugiego liczy się wiązane z przestrzenią odczucie jej „swojskości”. Naczelnym pojęciem jego rozważań staje się pojęcie „dom”. Jeśli jest on zamieszkany, to w sposób antropologiczny, przez ludzkie wspominanie miejsc, w którym przeszłość teraźniejszość i przyszłość wpływają na siebie. Kluczem staje się pojęcie „sen na jawie”. „Dom skrywa śnienie na jawie, dom chroni marzyciela, dom pozwala mu marzyć w spokoju” (Bachelard 
1994, s. 6). Zamieszkać dom to móc w nim śnić, doświadczać go, przeżywać. I wreszcie - wypowiadać. Sen na jawie jest bowiem możliwy dzięki słowom, które uruchomiają wyobraźnię. Dom zatem oznacza schronienie i poczucie bezpieczeństwa.

Jaką rolę $\mathrm{w}$ tym marzeniu dziennym odgrywają przedmioty wypełniające wnętrza? Bachelard pisze, że za sprawą procesów symbolizacji znaczeń w świadomości przedmioty dostarczają nam modeli myślenia i wyobrażenia rzeczywistości. „Garderoby z ich półkami, półki z szufladami i komody z fałszywym dnem są wiarygodnymi organami ukrytego życia psychicznego. W istocie, bez tych "przedmiotów», oraz kilku innych równie ważnych, naszemu intymnemu życiu mogłoby brakować modelu intymności. Są przedmiotami hybrydycznymi, prywatnymi przedmiotami" (Bachelard 1994, s. 78). Intymna przestrzeń Buczyńska-Garewicz (2006, s. 216) nazywa ją „przestrzenią osobną” — w rozumieniu Bachelarda to przestrzeń nie dla każdego otwarta. Wszystkie analizowane przez niego metafory odnoszą się do tego, co skryte: szuflady, szkatułki, gniazda, muszle mieszczą w sobie intymne światy, dostępne ich mieszkańcom. Dom wypełniony przedmiotami, w którego kącie można się schować, reprezentuje bezpieczną przestrzeń, do której można powracać także po latach, $\mathrm{w}$ pamięci.

Nadrzędnym tematem naszych rozważań nie są słowa, lecz obrazy. Jednak Bachelard analizuje obrazy przedmiotów utkane ze słów, a nas nie interesują wyłącznie te intymne obrazy powstające w ludzkiej wyobraźni, lecz obrazy zmaterializowane $\mathrm{w}$ fotografii. Tutaj już nie można swobodnie błądzić myślami, zdjęcia bowiem pokazują dość konkretnie - kształty i formy. Czy fotografie wnętrz mogą mieć zatem podobną moc budzenia wyobrażeń jako obrazy poetyckie? Wydaje się, że także na zdjęciu każdy przedmiot reprezentuje wiele innych, prywatnych, skrywających się za jego wyglądem. Bachelard (1994, s. 79) cytuje Miłosza: „Wspomnienia tłoczą się, kiedy spoglądamy wstecz na półkę, na której wyszywane jedwabiem batystowe i muślinowe tkaniny leżą na cięższych materiałach". Stajemy się podmiotami podobnego doświadczenia, kiedy oglądamy fotografie. Nie tylko szafy, także fotografie „wypełnia milczący tumult wspomnień". Podczas obserwacji przedmiotu na zdjęciu nasz umysł tworzy nowe wyobrażenia, przywołuje wspomnienia innych przedmiotów.

Spójrzmy na fotografię Reiko Imoto z cyklu: „Sny kogoś, kto utracił pamięć”, będącego fragmentem wystawy „Dreamscapes”. W centralnej części zdjęcia widzimy szklaną kulę na trójnogu. Ostrość rozmywa się ku brzegom kadru, nadal możemy rozpoznać zarys ścian, chociaż obraz nie dostarcza pewności, czy otaczają wnętrze, czy ciasne podwórko. Imoto opowiada sytuację odwrotną do historii Bachelarda, ponieważ wspomnienia zostały przecież utracone. Jednak $z$ drugiej strony tym bardziej tłoczą się nieokreślone skojarzenia. Utrata wspomnień nie musi oznaczać, że znikają one całkowicie, lecz że straciliśmy kontekst, klucz do ich odczytania. Autorka komentuje swoje prace: „czuję, jakby moje wspomnienia i sny uwięzły w «szufladzie» mojej podświadomości 
i jakbym nie mogła znaleźć «klucza» do niej” (Imoto 2007, s. 14). Na określenie chaosu pamięci używa ona tych samych metafor, które analizuje Bachelard: znów pojawiają się szuflady, klucze. Jakbyśmy nie potrafili myśleć inaczej niż poprzez przedmioty. Chociaż fotografie te można nazwać nostalgicznymi, to przecież nie ich nostalgiczny wydźwięk jest tu najważniejszy, ale pytanie, czy obraz fotograficzny może dać marzycielowi podstawę to śnienia na jawie. „Pejzaże marzeń" (dreamscapes) są taką właśnie próbą. Marzymy, rekonstruujemy zapomnianą przeszłość poprzez przedmiot. Zauważmy, że w niektórych praktykach psychoterapeutycznych kontakt z przedmiotem może przywrócić pamięć komuś, kto ją utracił. Szklana kula przepełniona światłem nie wróży tym razem przyszłości, lecz wskazuje na przeszłość.

Wyobrażenie wnętrza w kulturze Zachodu stanowi odpowiednik wnętrza duchowego. Można jednak zinterpretować rolę przedmiotów w naszym życiu $\mathrm{w}$ sposób nie tyle poetycki, ile materialistyczny i tak uzasadnić fetyszyzm towarowy kultury Zachodu w sposób duchowy. To, że otaczamy się przedmiotami, że „mówią nami” znaki towarowe, jest konsekwencją społecznych i kulturowych zmian, które przyniosła nowoczesność. Bez przedmiotów nowoczesny człowiek nie wie, kim jest. Dlatego już od czasu tekstu Waltera Benjamina badacze uznają, że wnętrze może reprezentować klasy społeczne. Wnętrza mieszkalne opisywane we fragmencie Paryża - stolicy dziewiętnastego wieku wypełnione są śladami życia prywatnego. Po raz pierwszy w nowoczesności, pisze filozof, jednostka ma prawo do prywatności i do zdefiniowania własnej tożsamości poprzez zbieranie przedmiotów. „Wnętrze jest dla osoby prywatnej czymś $\mathrm{w}$ rodzaju wszechświata. W nim gromadzi ona to, co dalekie i co przeszłe" - zauważa Benjamin (1996b, s. 326). Ten mikrokosmos przedmiotów nie tylko zapewnia poczucie bezpieczeństwa, daje także władzę nad światem.

Prace Weroniki Łodzińskiej i Andrzeja Kramarza z cyklu „Dom” mogłyby być niemal ilustracją tezy Benjamina. Oglądamy wypełnione przedmiotami wnętrza. Każde $z$ nich zostaje podpisane nazwą zawodu, który wykonuje jego mieszkaniec. Autorzy, przedstawiając nam „filozofa” czy „aktora”, nie pokazują - jak czynił to Sander - jego twarzy, lecz rzeczy, którymi się otacza. Tak jakby ludzie byli dosłownie (jak w malarstwie Arcimbolda) „zrobieni” z przedmiotów. Omawiane fotografie rzucają nowe światło na pytanie o dualizm sfery publicznej i prywatnej. Wnętrza pokazują przecież intymny świat ich mieszkańców, lecz jednocześnie definiują ich rolę społeczną.

Równie ciekawą wariacją na temat Benjaminowskiego podejścia do kolekcjonowania przedmiotów mógłby być również inny cykl tych samych fotografów, kontynuujący temat „Domu”. Fotografie zostały zrobione w noclegowni dla mężczyzn w Nowej Hucie w 2004 r. Pokazują łóżka, na których nocują bezdomni. Projekt można czytać dwojako: po pierwsze, jako socjologiczny opis warunków życia ludzi z marginesu społecznego, po drugie - co mnie wydaje się ciekawsze - jako pytanie o to, czym jest ten „dom”. Autorzy celowo prowokują 
widzów, nazywając „domem” miejsca, które zasadniczo nim nie są. Ponadto każą na nowo przemyśleć pojęcie bezdomności. Okazuje się bowiem, że chociaż bezdomność funkcjonuje jako termin operacyjny w teorii społecznej, to antropologicznie wcale nie pokrywa się z prostym rozróżnieniem dom = zamieszkanie; brak domu = bezdomność. O istnieniu domu stanowią prywatne przedmioty. Miejsce, w którym je składamy, może być (i coraz częściej jest) zmienne.

W komentarzu do cyklu fotografii Łodzińskiej i Kramarza Tadeusz Nowak pisze: „Autorzy projektu, zafascynowani zjawiskiem domu, fotografują wnętrza, które naturalnie stają się opisem ich właścicieli" 2 . Zastanówmy się nad sensem tego krótkiego cytatu. Czy w istocie możemy założyć, że relacja wnętrze-człowiek jest naturalna? Wydaje się raczej, że związek człowieka i wnętrza jest wyznaczony kulturowo (a zwłaszcza współczesny nadmiar przedmiotów) i jest zjawiskiem charakterystycznym dla obecnego stanu istnienia kultur. Przecież nawet kult przedmiotów, rytuały kultur pierwotnych (opisywane przez antropologów) nie określały tożsamości jednostki, lecz oznaczały przynależność i miejsce w grupie. Nie były oparte na indywidualnych upodobaniach, lecz na tradycji społeczności. Jednocześnie istnieją przecież kultury, które przedmiotów się wyrzekają, by nie rozpraszać swej duchowości. Czy przedmioty mogą opisywać właścicieli? Z pewnością dostarczają tropów do opowieści o ich życiu. Autorzy projektu „Dom”, jak się wydaje, badają tożsamość ludzką tak, jak czynią to detektywi na miejscu zbrodni. Przy celowym pominięciu osoby portretowanego, której twarz nie rozprasza uwagi śledczych, w przedmiotach wypatrują jego tożsamości. Nacisk zostaje położony na indywidualne historie, nie na społeczne przypisanie. Każdego do obecnego „domu” przyprowadziły inne koleje losu.

Na pozór wydaje się, że na fotografiach z omawianego cyklu nie widzimy domów w Bachelardowskim rozumieniu, to nie są domy szczęśliwego dzieciństwa, które mogłyby dać poczucie bezpieczeństwa na dalsze życie. Każdy $z$ „domów” na zdjęciu zostaje wyznaczony granicami łóżka i kawałka ściany w przytułku. Mimo to również ta przestrzeń, wypełniona przedmiotami i zdjęciami, daje podstawowe schronienie, także ona pozwala powiązać wspomnienia $z$ konkretnymi miejscami. Ten dom to bardziej dom wyobrażony niż rzeczywisty. Tutaj człowiek musi być marzycielem nie dla doświadczania świata poetyckiego, lecz by przetrwać trudności codziennej egzystencji. Zakwestionowane zostaje kolejne równanie budynek noclegowni $=$ dom. Nie ma bowiem możliwości „zamieszkania” noclegowni. W niej się nie mieszka, tylko „nocuje” — spędza czas przejściowo. Jej użytkownicy konstruują własną przestrzeń jak muszlę ślimaka, są gotowi na opuszczenie noclegowni, lecz zabierają wówczas własny „dom” złożony z prywatnych przedmiotów — wspomnień.

\footnotetext{
2 Tadeusz Nowak, Dom http://yoursgallery.home.pl/exhibitions.php?action=details\&exh_id= 14 [5.02.2010].
} 
Wydawałoby się, że trop, który sprawdził się w wypadku „Domu”, będzie równie efektywny w cyklu „Pokoi panieńskich” realizowanym przez Łodzińską w 2007 r. Tym razem fotografka rejestruje wnętrza, w których mieszkają młode koptyjki z kairskiej dzielnicy biedoty. Także tutaj pokoje pokazują nie tyle miejsce, które jest zamieszkane przez bohaterki dokumentu, ile miejsce, z którego chce się uciec. Potwierdzają to towarzyszące zdjęciom historie dziewczyn. Niektóre mają już wybranego męża i za chwilę przeniosą się do jego domu. Inne uczą się, by móc samodzielnie się utrzymać. Wszystkie wypełniają swoją przestrzeń marzeniami o „lepszym życiu”. „Pokój panieński” to miejsce przejściowe, miejsce, które się pozostawi.

Czy jednak zdjęcia z cyklu pokoi panieńskich mówią nam cokolwiek o jego mieszkankach? Pokoje, w których mieszkają dziewczyny, wypełnia łóżko oraz kilka portretów rodzinnych i świętych obrazów. Tutaj nie ma tych zachodnich bibelotów, którymi się otaczamy, chcąc stworzyć obraz siebie. Tutaj jest opis, lecz nie ma opowiadania. To dopiero komentarz towarzyszący fotografiom wyjaśnia kontekst społeczny, „lokalizuje” miejsce. Jakby moc tworzenia narracji rozbijała się o surowe ściany. Jeśli o czymś te pokoje mogą dostarczyć nam informacji, to o warunkach społecznych, lecz nie o poszczególnych osobach. Zdają się niezamieszkane, chociaż bez wątpienia ktoś w nich przebywał. Kult przedmiotu, tak charakterystyczny dla kontekstu Zachodu, okazuje się zasadniczo niewystarczający, jeżeli spoglądając przez jego pryzmat chcemy wypowiadać się o innej kulturze.

Gdy patrzymy na obrazy, nie sposób odciąć się od naturalnego dla człowieka sposobu komunikowania znaczeń dokonującego się poprzez procesy symboliczne. Chociaż więc współcześni fotografowie będą się posługiwali odniesieniem „naukowym”, to gdy ich prace znajdą się w galerii, dla odbiorcy staną się metaforami istnienia ludzkiego. Przedstawiana na początku teza Bourdieu, chociaż zasadniczo słuszna, nie pozwala wziąć pod uwagę owego kontekstu miejsca, w którym patrzymy na obrazy. W galerii zaś zmieniamy fotografie w symbole i zaczynamy wędrować drogą Bachelardowskiej wyobraźni, a nie tropem rzeczywistości na nich zapisanych. Droga rozmyślania toczy się swobodnie. Teraz musimy wyobrazić sobie mieszkańca sfotografowanego wnętrza. Kim jest właścicielka tego pokoju? Ponieważ faktów jest niewiele, także jej obraz początkowo ukazuje się zamazany. Staje się bardziej konkretny nie dzięki przedmiotom, lecz naszemu o niej wyobrażeniu.

\section{PORTRET WNĘTRZA}

Kontekst odbioru fotografii jest ważny, zmienia bowiem naszą interpretację. Fotografie uparcie wpisywane w kontekst socjologiczny nabierają odmiennych znaczeń, gdy pojawiają się w kontekście estetycznym. A zauważmy, że tak na ogół z pracami, które zostały tu omówione, stykamy się w galeriach i muzeach. Kontekst społeczny tych prac zawsze zostaje więc uzupełniony estetycznym. 
Mieke Bal (2006, s. 354) pisze: „obraz mówi, posiada znaczenie kulturowe, które może dostarczyć nam wiedzy na temat kultury, w jakiej został stworzony [...] a także udostępnia nam te znaczenia pod warunkiem, iż potrafimy go odczytać, umieścić w kontekście, który owe znaczenia uwypukla”. Co dzieje się, gdy socjologiczną bazę danych pokazuje się nam w galerii? Odmienny kontekst, jakim jest galeria, sprawia, że patrzymy na te zdjęcia inaczej, czytamy je nie tylko poprzez warstwę opisową, ważną dla badacza, lecz przede wszystkim poprzez sferę estetyczną. Sięgając do przykładów, którymi tu się posługujemy, można powiedzieć, że w każdym $z$ opisywanych wypadków oglądamy obraz wnętrza we wnętrzu galerii czy muzeum (czy czasem w przestrzeni zewnętrznej). Ten kontekst odbioru musi wpływać na nasze ich odczytanie.

Pytanie, które chcę tutaj zadać, brzmi: Czy na fotografii wnętrz widzimy zawsze rzeczy, czy też jesteśmy zdolni zobaczyć także miejsce? „Wyznaczanie miejsca przez rzecz - pisze Hanna Buczyńska-Garewicz (2006, s. 98) nie tylko odwraca "przestrzenny" sposób myślenia o miejscu i rzeczy, w którym miejsce poprzedza rzecz, a rzecz umieszcza się w miejscu), lecz także nadaje konkretny i wypełniony zawsze jakąś treścią sens miejsca". Fotografia wyznacza właśnie miejsce poprzez rzecz. A dzieje się tak, ponieważ jak zauważa Hans Belting (2007, s. 77) - obrazy fotograficzne „wyjmują” przedmioty $z$ ich kontekstu geograficznego, przesuwają je, wyrywają. W pewien sposób pozbawiają je miejsca czy może raczej zmieniają je w „miejsca nieumiejscowionego".

Od czasu pojawienia się obrazów medialnych wcześniejsze rozumienie miejsca uległo rozpadowi. Obrazy miejsc zastępują same miejsca. Kiedyś trzeba było „być w miejscu”, by je widzieć, dzisiaj można wiedzieć o miejscu wszystko, chociaż nigdy fizycznie w nim się nie było (Belting 2007, s. 77). Ta refleksja filozofa ma konsekwencje również dla naszego myślenia o wnętrzach. Oto nagle bowiem, patrząc na zdjęcie wnętrza, możemy założyć, że mogą istnieć takie wnętrza, które nie mają swojego zewnętrza. Wnętrze pałacu może okazać się makietą, przecież znamy je tylko z fotografii. Jak pisze Belting (2007, s. 89), miejsca współcześnie nie są już interpretowane w kontekście geograficznym czy historycznym, tracimy odniesienie do tego, co kiedyś było pojmowane jako „daleko” czy „kiedyś”. Można by więc powiedzieć, komentując myśl Beltinga, że fotografie materialnie dostarczają nam obrazów miejsc, które zawsze będą już „tu” i „teraz” w zasięgu oka.

Przywołajmy w tym kontekście prace fotografki, która całkowicie zmienia antropologiczną perspektywę „portretu we wnętrzu”. Candida Höfer nie fotografuje ludzi, lecz miejsca. Znakomicie to widać w pracach eksponowanych podczas 50 Biennale Sztuki w Wenecji. W jej fotografiach, pokazujących miejsca użyteczności publicznej, wnętrze nie odnosi się już do próby ustalenia tożsamości mieszkańca, lecz zaczyna reprezentować instytucje społeczne. Autorka nie wprowadza tu refleksji nad indywidualnymi tożsamościami - niepewnej i mglistej. To, co robi, jest o wiele bardziej „przejrzyste” pod względem fotogra- 
ficznym. Sporządza opis, który nie pozwala się opowiedzieć (nie znaczy to, że nie można go zinterpretować). To po prostu obraz. Jasny i przejrzysty. Żadnych zapożyczeń, żadnych niejasności. Rzeczy sfotografowane stwarzają miejsce, klasyfikują je przez przynależność do jednego z gatunków miejsc publicznych - bibliotek, galerii, sal koncertowych. Pokazanie tożsamości przez rzeczy? Sporządzanie portretów? Przedmioty, które u Łodzińskiej mogły składać się na socjologiczną bazę danych (o życiu młodych Koptyjek), w konceptualnej interpretacji Niemki stają się elementami portretu miejsca, lecz już nie jego użytkowników. Teraz wreszcie samo wnętrze staje się bohaterem fotografii, uwolnione od człowieka.

Przywołajmy powtórnie analizowane wcześniej prace Łodzińskiej i Kramarza. Tam przedmiot reprezentował ludzką tożsamość w kontekście pełnionej przez niego roli społecznej. Tutaj przedmiot reprezentuje instytucje kultury i podobnie jak w przypadku praktyki portretowej buduje wizualne archiwum. Jednak sens owego archiwum dotyczy czego innego - nie tyle ludzi, ile miejsc. Oto jak problem podejmowany przez Höfer opisuje Julian Heynen, kurator pawilonu niemieckiego na pięćdziesiątym Biennale Sztuki w Wenecji: „miejsce dzieła sztuki. Miejsce artysty. Miejsce widza. Miejsce i tożsamość. Tożsamość miejsca. To miejsce i tamto miejsce. Wszystkie możliwe miejsca. Wszystkie miejsca możliwe do wyobrażenia" (50 ${ }^{\text {th }}$ International Art Exhibition, 2003, s. 533). Te fotografie pokazują, jak rozpadł się związek człowieka z miejscem, w którym przebywa. Znów można by odnaleźć bardzo szczególne powiązanie $z$ Heideggerowską interpretacją. Filozof pytał tam, jak „zamieszkać" budynki publiczne, w których się pracuje, lub konstrukcje, po których - jak po moście - tylko się przechodzi. Nadal jednak wiązał owe budowle z osadzeniem w miejscu, w którym powstały (Heidegger 2007, s. 139-140). „Most skupia wokół rzeki ziemię jako krajobraz” (Heidegger 2007, s. 147), a tym samym staje się miejscem i przydziela przestrzeń. Możliwość delokalizacji miejsc, którą daje fotografia, każe przemyśleć na nowo takie rozumienie. Teraz, co prawda, nadal rzecz stanowi miejsce, lecz przestrzeń, w której je lokujemy, za każdym razem może być nowa. W cyklu fotografii „Zwölf Twelve", poświęconym peregrynacjom muzealnym Mieszczan $z$ Calais Rodina (2000), Höfer pokazuje, jak rzecz-obiekt zmienia przestrzenie - raz przebywając w muzeum w Bazylei, innym razem w Kopenhadze. Fotografia może skupić wokół siebie topograficznie określoną przestrzeń tylko chwilowo, nigdy na stałe.

Odeszłam na chwilę w swojej argumentacji od tematyki wnętrza ku problemowi miejsca. Uczyniłam to, by pokazać jak to, co w przeszłości rozumiane było jako wnętrze - pewna stała własność, związana z czasem i przestrzenią, współcześnie uległo przekształceniu. Może być negocjowane zarówno jako tożsamość, jak i jako miejsce. Powróćmy do Beltinga (2007, s. 87): „nomadyczny obywatel świata, który już w żadnym geograficznym miejscu nie czuje się u siebie, niesie w sobie obrazy, którym raz jeszcze - w przemijalnym 
życiu, jego własnym życiu - użycza miejsca". To miejsce w ciele człowieka stanowi właśnie owo poszukiwane przez nas „wnętrze”, uwolnione już z geografii.

Wnętrze reprezentujące tożsamość stanowi zarówno metaforę, jak i metodę porządkująca nasz sposób patrzenia na społeczeństwo. Jednak by móc rozpracować znaczenia ich funkcjonowania, potrzebujemy podejścia interdyscyplinarnego, czerpiącego zarówno z nauk społecznych, jak i z nauk o kulturze. Ich wzajemna relacja oraz rysujące się między tymi podejściami punkty sporu (tak przeciwstawne jak dyskurs estetyczny czy ideologiczny) wyznaczają współczesny dyskurs społeczny fotografii. Jego nadrzędną cechą jest jednak pytanie o to, w jaki kompleks znaczeń społecznych i kulturowych uwikłana jest dzisiaj fotografia.

\section{BIBLIOGRAFIA}

Bachelard Gaston, 1994, The Poetics of Space: The Classic Look at How We Experience Intimate Places, tłum. Maria Jolas, Beacon Press, Boston.

Bal Mieke, 2006, Dyskurs muzeum, tłum. Małgorzata Nitka, w: Maria Popczyk (red.), Muzeum sztuki. Antologia, Universitas, Kraków.

Barthes Roland, 1996, Światto obrazu. Uwagi o fotografii, tłum. Jacek Trznadel, Wydawnictwo KR, Warszawa.

Belting Hans, 2007, Antropologia obrazu. Szkice do nauki o obrazie, tłum. Mariusz Bryl, Universitas, Kraków.

Benjamin Walter, 1996a, Mała historia fotografii, tłum. Janusz Sikorski, w: Walter Benjamin, Aniot historii. Eseje, szkice, fragmenty, Wydawnictwo Poznańskie, Poznań.

Benjamin Walter, 1996b, Paryż — stolica dziewiętnastego wieku, tłum. Hubert Orłowski, w: Walter Benjamin, Anioł historii. Eseje, szkice, fragmenty, Wydawnictwo Poznańskie, Poznań.

Berger John, 1999, O patrzeniu, tłum. Sławomir Sikora, Fundacja Aletheia, Warszawa.

Bourdieu Pierre, 1990, Photography: A Middle-brow Art, tłum. Shaun Whiteside, Polity Press, Oxford.

Buczyńska-Garewicz Hanna, 2006, Miejsca, strony, okolice. Przyczynek do fenomenologii przestrzeni, Universitas, Kraków.

Czartoryska Urszula, 2005a, Użytki spoteczne fotografii, w: Urszula Czartoryska, Fotografia - mowa ludzka. Perspektywy teoretyczne, słowo/obraz terytoria, Gdańsk.

Czartoryska Urszula, 2005b, W kregu teorii Benjamina, w: Urszula Czartoryska, Fotografia - mowa ludzka. Perspektywy teoretyczne, słowo/obraz terytoria, Gdańsk.

Hamon Philippe, 2004, Czym jest opis?, w: Michał Głowiński (red.), Narratologia, słowo/obraz terytoria, Gdańsk.

Heidegger Martin, 2007, Budować, mieszkać, myśleć, w: Martin Heidegger, Odczyty i rozprawy, tłum. Janusz Mizera, Aletheia, Warszawa.

Heynen Julian, 2003, w: $50^{\text {th }}$ International Art Exhibition. Dreams and Conflicts: The Dictatorship of the Viewer, red. F. Bonami, M. L. Frisa, katalog wystawy, La Biennale di Venezia, Wenecja.

Imoto Reiko, 2007, Dreamscapes, OKiS, Wrocław.

Sikora Sławomir, 2004, Fotografia między dokumentem a symbolem, IS PAN, Izabelin. 
Tagg John, 1988, The Burden of Representation, Palgrave, Macmillan, New York.

Vidler Anthony, 1999, The Explosion of Space, w: Film Architecture, Dietrich Neumann (red.), Prestel, Münich-London-New York.

\section{PORTRAIT IN AN INTERIOR — BETWEEN THE SOCIOLOGY AND ANTHROPOLOGY OF PHOTOGRAPHY}

\section{Summary}

This text is an attempt to analyze the works of a selection of contemporary artistic photographers (including Weronika Łodzińska, Reiko Imoto and Todda Hido) from the perspective of sociology and visual anthropology. The first is represented by the texts of Pierre Bourdieu as well as John Tagg, while the latter by Hans Belting and Gaston Bachelard. The author examines the photographic manner of picturing society and the cultural identity of the subjects - from the typical studio portrait through social projects (August Sander) to contemporary documentary photography in which the identity of the individual and their social position is shown without the presence of a model (Candida Höfer).

\section{Key words/słowa kluczowe}

social photography / fotografia społeczna; photographic portrait / portret fotograficzny; anthropology of image / antropologia obrazu; space / rzestrzeń; interior / wnętrze 